\title{
Solar septic tanks: A new sanitation paradigm for Thailand 4.0
}

\author{
Chongrak Polprasert $^{\mathrm{a}, *}$, Thammarat Koottatep ${ }^{\mathrm{b}}$, Tatchai Pussayanavin ${ }^{\mathrm{b}, \mathrm{c}}$ \\ a Department of Civil Engineering, Faculty of Engineering, Thammasat University, \\ Pathumthani 12120 Thailand \\ b School of Environment, Resources and Development, Asian Institute of Technology, Klong Luang, \\ Pathumthani 12120 Thailand \\ c Faculty of Science and Technology, Phranakhon Rajabhat University, Thailand \\ *Corresponding author, e-mail: pchongrak@gmail.com
}

\begin{abstract}
At present, 99\% of Thai people have access to basic sanitation facilities, but pollution from human wastewater and excreta poses serious environmental and health problems nationwide. Due to its high treatment efficiency and low investment cost, a solar septic tank has been developed as an innovative technology for domestic wastewater treatment. It is being considered as a new sanitation paradigm to fulfil the Thailand 4.0 policy and make a significant change in the country's environment to become a liveable society.
\end{abstract}

KEYWORDS: sanitation situation, pollution, disease

\section{PRESENT SANITATION SITUATIONS AND PROBLEMS}

According to the United Nations and World Health Organization reports ${ }^{1-3}$, more than 2 billion people currently live without access to basic sanitation, causing negative impacts not only on environmental pollution but also serious water bone diseases infection to humans. For example, due to unsafe water supply and improper basic sanitation, there are more than one million deaths of children every year in the Sub-Saharan Africa and Asia.

Before 1960, Thailand did not have appropriate methods for toilet wastewater or blackwater treatment. Pit latrines and cesspools were commonly used for the black water treatment which have caused the spreading of pathogens in the environment and disease infection to people living nearby the vicinity, e.g., the numbers of diarrhoea cases were approximately 1 million per year ${ }^{4}$.

To alleviate the above problem in Thailand, the Thai government assigned the period of 19811990 as the "decade of water supply and sanitation in Thailand" in line with the United Nations declaration. As shown in Fig. 1, the sanitation infrastructure systems generally have 3 components, i.e., toilet, onsite wastewater treatment and faecal sludge management. Each or all components can be located onsite close to the source of waste generation. Although at present, Thailand has coverage of nearly $99 \%$ of basic sanitation facilities to all the people, pollution from wastewater still causes serious environmental and health problems nationwide.

Because of high investment cost and requirement of skilled operation, large investment of sewerage associated with centralized treatment systems is the barrier for construction of wastewater management systems in Thailand ${ }^{5}$.

During 1991-1996, the Department of Health, Thailand, promoted changing the type of onsite wastewater treatments from cesspools to septic tanks (Fig. 2). However, in developing countries septic tanks do not perform satisfactorily due to improper design (such as configuration, sizing and hydraulic retention time) and limitations on operation including absence of post treatments and leaching fields ${ }^{6}$. Some previous studies found that septic tanks could reduce organic matter, nutrient, and pathogens only $20-50 \%$ and the effluent concentrations of septic tanks were found to contain $\mathrm{BOD}_{5}$ of $90-160 \mathrm{mg} / 1$ and faecal coliforms of $10^{5}$ $10^{8} \mathrm{MPN} / 100 \mathrm{ml}^{6-8}$, higher than the standards for discharge and causing water pollution and high health risks ${ }^{9}$.

\section{DEVELOPMENT OF SOLAR SEPTIC TANKS}

Since 2012, the Bill \& Melinda Gates Foundation has supported several research projects to reinvent the sanitation technologies to alleviate the above problems. The main aim of these projects was to develop effective onsite sanitation technologies, that low-income people can have access and to create 


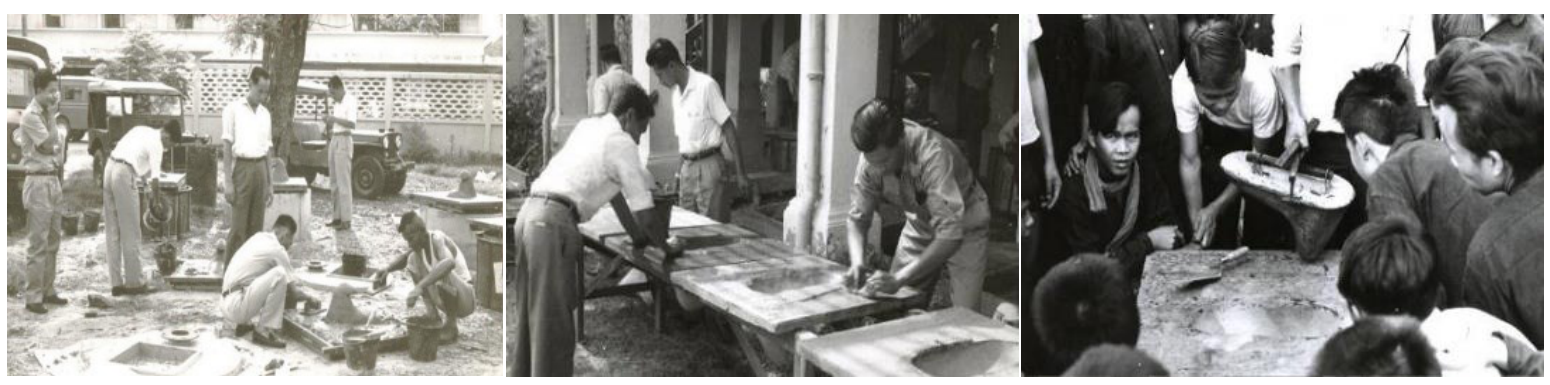

Fig. 1 Development of basic sanitation infrastructure in Thailand (credits: Twisuk Punpeng, Department of Health, Ministry of Public Health, 2007).

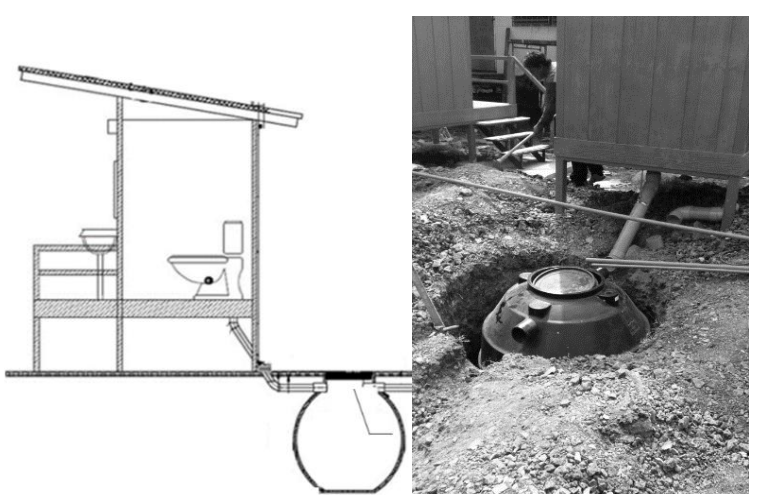

Fig. 2 Conventional septic tank.

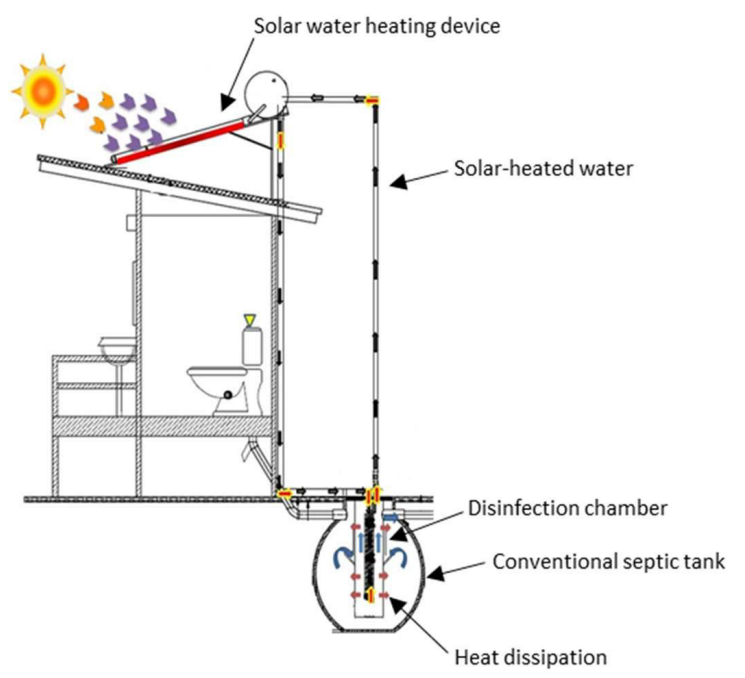

Fig. 3 Solar septic tank.

a platform of global sustainability. One of the innovative sanitation technologies developed is solar septic tanks (Fig. 3) which utilize solar-heated water to increase wastewater treatment and pathogen inactivation efficiencies in the septic tanks.
The solar septic tank system improves on the traditional septic tank by harnessing solar energy via water filled, tube solar collectors that use energy from sunlight to heat water circulated to heat the septic tank content. Temperatures in the solar septic tank could be increased up to $40-55^{\circ} \mathrm{C}$ by this solar water heating device equipped with a control panel and a temperature sensor, effective for inactivating the pathogens. A typical solar septic tank consists of 3 main components: (i) 1000 l-conventional septic tank, (ii) disinfection chamber, and (iii) solar water heating device. Temperatures inside the septic tank is increased by circulating hot water generated from the solar water heating device through a heat transfer equipment (copper coil). To maintain the temperature in range of $40-55^{\circ} \mathrm{C}$ inside the solar septic tank, the hot water is circulated at a rate of $3-51 /$ min which naturally results in increased rate of biodegradation, reduced solid accumulation and consequently reduced frequency of sludge emptying. Further, and perhaps more vitally, the effluent passes through the disinfection chamber (Fig. 3) where the temperature could be in excess of $55^{\circ} \mathrm{C}$ which effectively inactivates the faecal pathogens. Thus the solar septic tank produces a significantly higher quality effluent and contributes to environmental improvement and health risk reduction ${ }^{10,11}$.

\section{PERFORMANCE AND SELECTED CASE STUDIES OF SOLAR SEPTIC TANKS}

The pilot-scale solar septic tanks have been tested at several housing communities and institutions in Thailand, Cambodia, and India. Some selected case studies and their performance are briefly described below.

\section{Housing community, Santavee factory, Samutprakarn province, central Thailand}

Field testings of a 10001 solar septic tank has been in operation at the Santavee factory since March 


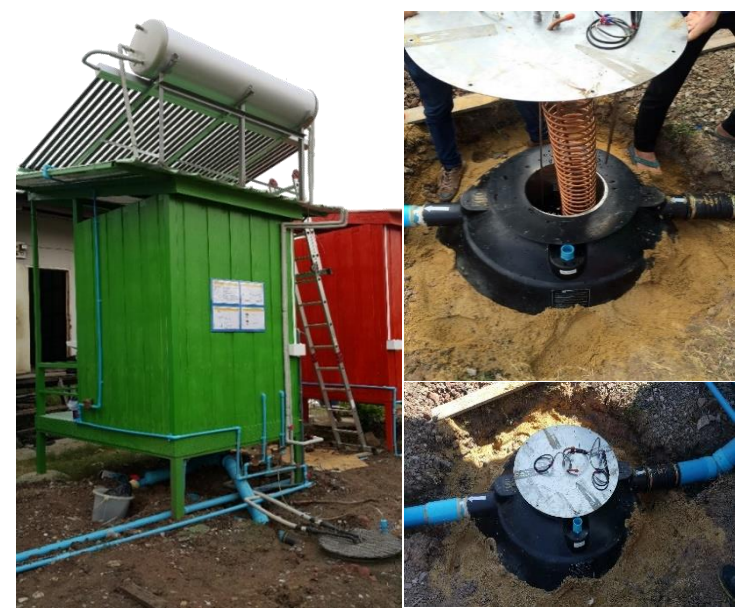

Fig. 4 Field testing of solar septic tank at Santavee factory.

2015 to evaluate its performance under actual conditions including fluctuating flow rate and ambient temperature (Fig. 4). A conventional septic tank of equal size but without solar water heating device, was operated in parallel for comparison. These twoseptic tanks treat black water (excreta and flushing water) generated by the factory workers.

During the operation period, the average ambient temperature and solar radiation were about $32{ }^{\circ} \mathrm{C}$ and $200 \mathrm{~J} / \mathrm{m}^{2}$ per min, respectively. The temperature range in the solar septic tank equipped with the solar water heating device was about 40 $45^{\circ} \mathrm{C}$, while the hot water temperatures were $27-$ $65^{\circ} \mathrm{C}$ (Fig. 5a). The disinfection efficiencies of the solar septic tank operated at $40-53^{\circ} \mathrm{C}$ were about 2-4 log reduction of total coliform (TC) and 3-5 $\log$ reduction of $E$. coli, while the disinfection efficiencies of the conventional septic tank was found to be about $0-1 \log$ reduction of $E$. coli and total coliform (Fig. 5b). The E. coli concentrations of the solar septic tank effluent could be reduced to less than $10^{3} \mathrm{MPN} / 100 \mathrm{ml}$, and so the effluent is suitable for reuse or discharge to the environment ${ }^{13}$. The effluent COD and BODc concentrations of the solar septic tank were $120-730$ and 80 $350 \mathrm{mg} / \mathrm{l}$, respectively. These were lower than those of the conventional septic tank which were 200-1000 and 150-600 mg/l, respectively. For the sludge concentration, total solid and total volatile solid concentrations in the solar septic tanks were found to be 25000 and $16000 \mathrm{mg} / \mathrm{l}$, respectively, less than those in the conventional septic tank which were about 44000 and $28000 \mathrm{mg} / \mathrm{l}$, respectively. These results indicate that the solar septic tank
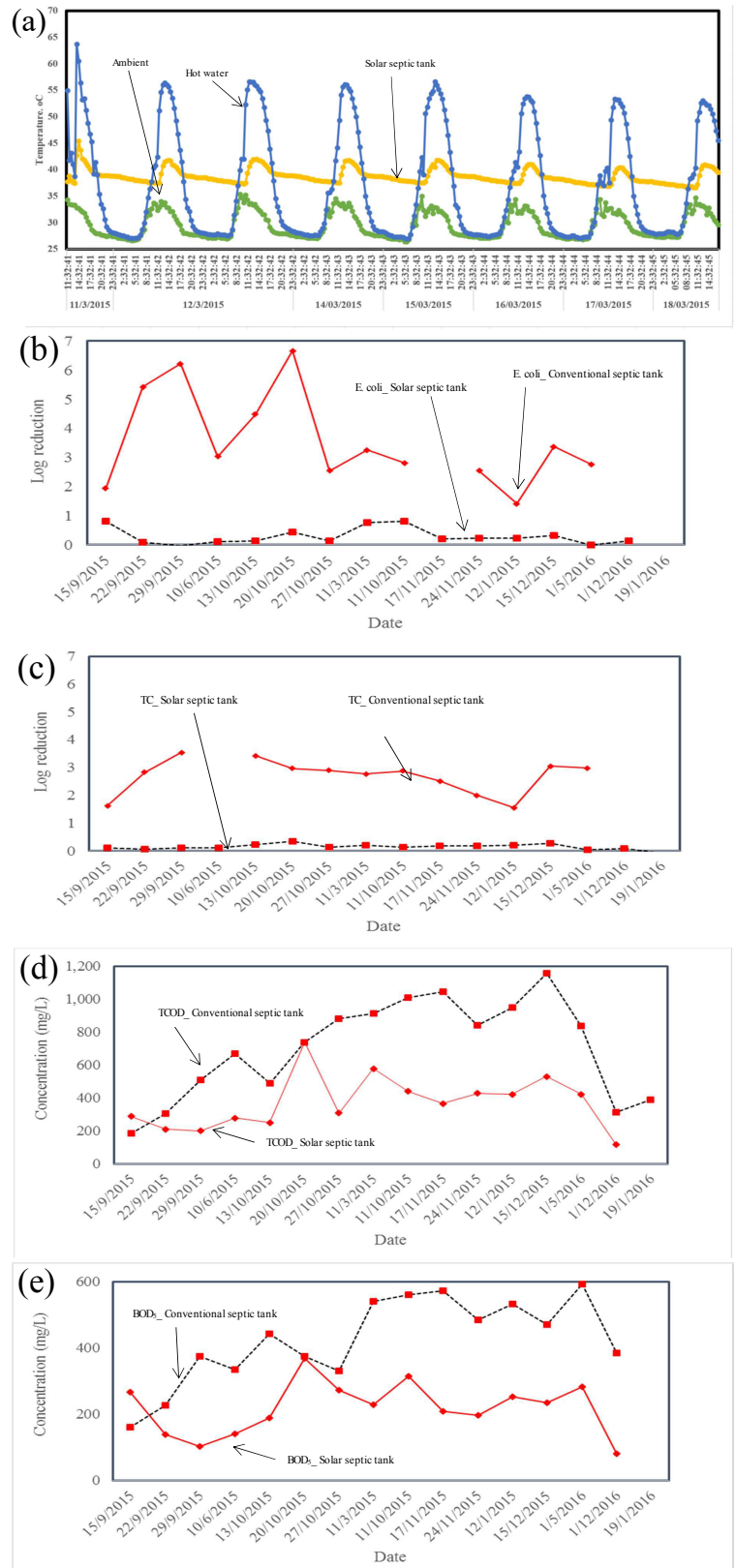

Fig. 5 (a) Temperatures profile in solar septic tank, (b) E. coli inactivation, (c) total coliform (TC) inactivation, (d) TCOD effluent concentration, and (e) $\mathrm{BOD}_{5}$ effluent concentration.

could biodegrade the organic matter and digest the accumulated sludge better than the conventional septic tank. The direct benefits gained from the increased temperature in the solar septic tanks were a lengthened period between successive desludgings and the reduced cost of septic tank sludge treatment, including improving the environmental situ- 

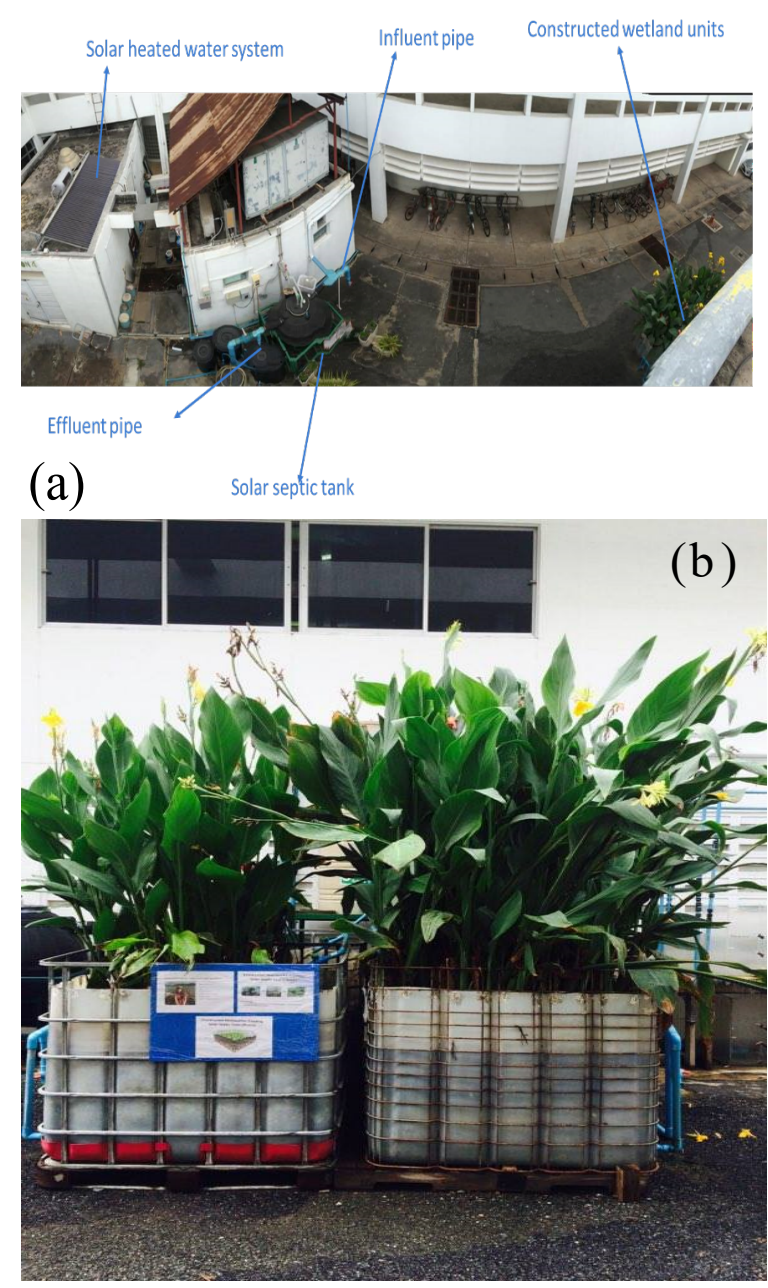

Fig. 6 Integration solar septic tank with constructed wetland for the treatment of black water.

ation of the receiving water and minimizing health risks.

\section{Academic building at the Asian Institute of Technology, Pathumthani, Thailand}

A 10001 solar septic tank equipped with a $12 \mathrm{~m}^{2}$ solar water heating device was constructed at the Ambient Laboratory of the Asian Institute of Technology, Thailand, to treat black water from the communal toilets (Fig. 6a). Hot water from the solar water heating device was circulated by a pump ( $31 / \mathrm{min}$ ) through a heat transfer equipment inside the septic tank. The vacuum tube solar collector employed as the solar water heating device (Fig. 6a) has 63 vacuum tubes with $12 \mathrm{~m}^{2}$ exposed area and peak Watts of 2.8 kilowatt. The solar septic tank was integrated with a 4- $\mathrm{m}^{2}$ vertical flow constructed wetland planted with two plant species,
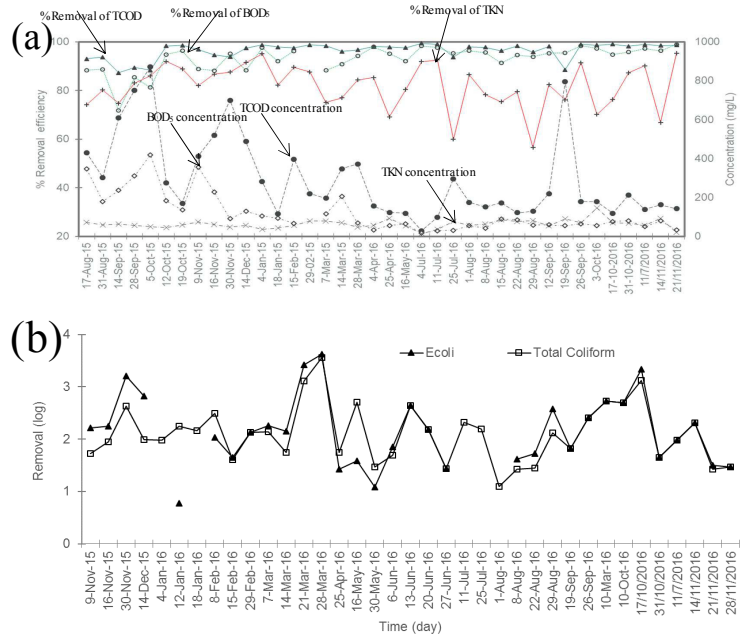

Fig. 7 Treatment performance of solar septic tank (a) organic matters and (b) pathogen indicators.

Table 1 Characteristics of effluent of integration of solar septic tank and constructed wetland system.

\begin{tabular}{lccc}
\hline Parameter & Unit & Concentration & Standard * \\
\hline TCOD & $\mathrm{mg} / 1$ & $45 \pm 9$ & \\
$\mathrm{BOD}_{5}$ & $\mathrm{mg} / 1$ & $7 \pm 3$ & $<200$ \\
$\mathrm{TKN}$ & $\mathrm{mg} / 1$ & $10 \pm 4$ & \\
$\mathrm{NH}_{3-} \mathrm{N}$ & $\mathrm{mg} / \mathrm{l}$ & $8 \pm 2$ & \\
$\mathrm{TP}$ & $\mathrm{mg} / 1$ & $1 \pm 1$ & \\
$\mathrm{TSS}$ & $\mathrm{mg} / 1$ & $19 \pm 7$ & $<60$ \\
$\mathrm{TC}$ & MPN/100ml & $6.83 \times 10^{2}$ & \\
E. coli & MPN/100ml & $3.37 \times 10^{2}$ & \\
\hline
\end{tabular}

" National Thailand standard 2010, Ministry of Natural Resources and environment of Thailand (MNSE). Definition of standard of wastewater discharge from domestic wastewater treatment plant in Thailand.

Canna siamensis and vetiver grass, under mixedculture plantation conditions (Fig. 6b).

Percentage of the solar septic tank (Fig. 7a) indicated the TCOD, SCOD, $\mathrm{BOD}_{5}, \mathrm{TS}$, and TVS removal efficiencies of about $85,76,80,35$, and $60 \%$, respectively. The disinfection efficiencies were similar at about $2.4 \log$ reduction of total coliform and $E$. coli (Fig. 7b). The solar septic tank effluent still contained $\mathrm{BOD}_{5}$ and TKN concentrations higher than the discharge standards in Thailand ${ }^{12}$ and further treatment with the constructed wetlands was required.

Performance of the integrated solar septic tankconstructed wetland system is shown in Table 1. The effluent $\mathrm{BOD}_{5}$ and TKN concentrations were lower than $20 \mathrm{mg} / \mathrm{l}$, while the effluent TCOD and, 
TSS concentrations were 45 and $19 \mathrm{mg} / \mathrm{l}$, respectively, within the effluent standards of Thailand. The total coliform and $E$. coli concentrations were less than $10^{3} \mathrm{MPN} / 100 \mathrm{ml}$, suitable for discharge or reuse in agriculture ${ }^{13}$.

In addition to the above case studies, performance of the solar septic tanks installed at other places in Thailand, Cambodia, and India show similar trends as reported in Fig. 7 and Table 1, and their detailed data will be reported in the near future.

\section{APPLICABILITY AND BENEFITS OF SOLAR SEPTIC TANKS FOR THAILAND 4.0}

Since the 19th century, the sanitation paradigm in Thailand has passed through "Thailand 1.03.0" with emphasis placed on ineffective waste/ wastewater treatment technologies such as cesspools or septic tanks. Thus because of ineffective basic sanitation facilities, Thailand has become stuck with environmental problems. As the country needs to deal effectively with disparities and the imbalance between the environment and society, the Thailand 4.0 policy is focusing on a sustainable value-based economy. Having high treatment efficiencies and low construction cost, the solar septic tank has been developed as an innovative technology to fulfil the policy of Thailand 4.0 and should be considered as a new sanitation paradigm nationwide to improve the country's environment and contributing to development of a liveable society for Thailand.

Acknowledgements: This study was financially supported by the Bill \& Melinda Gates Foundation.

\section{REFERENCES}

1. United Nations (2014) United Nations Population Information Network, United Nations Population Division, Department of Economic and Social Affairs, UN, New York, www.un.org/popin.

2. United Nations Water (2009) Statistics, Graphs and Maps, Water Pollution, Environmental Degradation and Disasters, UN-Water, Geneva.

3. World Health Organization (2013) Lack of Water and Inadequate Sanitation, WHO, Geneva, www.who.int/ ceh/risks/cehwater/en.

4. Government of Thailand, Ministry of Public Health (2008) Fact sheet on environmental health. In: Managing Night Soil in Sub-Districts, vol 1, MOPH, Thailand.

5. Massoud MA, Tarhini A, Nasr JA (2009) Decentralized approaches to wastewater treatment and management: applicability in developing countries. J Environ Manag 90, 652-9.
6. Polprasert C, Rajput VS (1982) Septic Tank and Septic Systems: Environmental Sanitation Reviews, No. 7/8, ENSIC, Bangkok, Thailand.

7. Brandes M (1977) Characteristics of Effluents from Separate Tanks Treating Grey Water and Black Water from the Same House, Publication no. W 68, Applied Sciences Section Pollution Control Branch, Ministry of the Environment, Ontario, Canada.

8. Baumann ER, Babbitt HE (1953) An Investigation of the Performance of Six Small Septic Tanks, Univ of Illinois Engineering Experiment Station Bulletin Series no. 409, Univ of Illinois Bulletin vol 50, Urbana, IL.

9. Koottatep T, Phuphisith S, Pussayanavin T, Panuvatvanich A, Polprasert C (2014) Modeling of pathogen inactivation in thermal septic tanks. $J$ Water Sanit Hyg Dev 4, 81-8.

10. Pussayanavin T, Koottatep T, Eamrat R, Polprasert C (2015) Enhanced sludge reduction in septic tanks by increasing temperature. $J$ Environ Sci Health A 50, 81-9.

11. Koottatep T, Eamrat R, Pussayanavin T, Polprasert C (2014) Hydraulic evaluation and performance of onsite sanitation systems in central Thailand. Environ Eng Res 19, 269-74.

12. Pollution Control Department (2014) Housing Estate Standards, Pollution Control Department, Bangkok, Thailand, www.pcd.go.th.

13. World Health Organization (1989) Health Guidelines for the Use of Wastewater in Agriculture and Aquaculture, Report of a WHO Scientific Group, no. 778, WHO, Geneva. 